\title{
WACANA HUMOR PADA TAGAR \#MATANAJWAMENANTITERAWAN DI TWITTER
}

\author{
Novrita Widiyastuti \\ LSPR Communication and Business Institute, Jakarta - Indonesia \\ novrita.w@1spr.edu
}

\begin{abstract}
Mata Najwa, a talk show hosted by Najwa Shihab, on September 29, 2020 uploaded unusual video which questioning the existence of Terawan Agus Putranto, The Minister of Health Republic Indonesia at that time, whom never appears in the media to make statement about Government's treatment of pandemic Covid-19. Mata Najwa tried to attract public's attention by uploading a video that using empty chair interview technique, pretends Terawan was shows up in the middle of the show. Until the video with hastag \#MataNajwaMenantiTerawan became trending topic in Twitter and created new humor discourses from netizens. The humor discourses in this hashtag is interested to be researched, that makes the objective of this research is to discover humor discourses contained in the video \#MataNajwaMenantiTerawan, as well as user's tweets that created new humor discourses in Twitter. Concept framework of this research is concepts about satire, parody, parikena, dan sarcasm. Research method: constructivism paradigm with qualitative type of research. Data collection methods: observing video Mata Najwa duration 4 minutes 22 seconds, timeline on Twitter with hashtag \#MataNajwaMenantiTerawan, interview with Executive Producer of Mata Najwa from Narasi TV and documentation from various sources.
\end{abstract}

Keywords: Humor, Satire, Talkshow, Twitter

\begin{abstract}
Abstrak
Mata Najwa, sebuah gelar wicara yang dipandu Najwa Shihab pada tgl 29 September 2020, mengunggah video yang tidak biasanya, yaitu mempertanyakan keberadaan Terawan Agus Putranto, Menteri Kesehatan RI saat itu, yang sudah tidak tampil lagi di media untuk memberikan keterangan mengenai penanganan pandemi Covid-19. Mata Najwa mencoba untuk menarik perhatian publik dengan mengunggah video yang menggunakan teknik wawancara kursi kosong seolah-olah Terawan tengah hadir di acara tersebut. Hingga akhirnya video dengan tagar \#MataNajwaMenantiTerawan ini menjadi trending topic di Twitter, dan menciptakan wacana humor baru dari warganet. Wacana humor dalam tagar ini menarik untuk diteliti, sehingga tujuan dari penelitian ini adalah menemukan wacana humor yang terdapat pada video \#MataNajwaMenantiTerawan dan juga dari cuitan warganet yang menciptakan wacana humor baru di Twitter. Kerangka konsep dari penelitian ini adalah konsep-konsep mengenai satir, parodi, guyon parikena dan sarkasme. Metode penelitian: paradigma konstruktivis, jenis penelitian: kualitatif. Metode pengumpulan data: observasi video Mata Najwa berdurasi 4 menit 22 detik, linimasa Twitter dengan tagar \#MataNajwaMenantiTerawan, wawancara Produser Eksekutif Narasi TV dan dokumentasi dari berbagai sumber. Hasil penelitian menyebutkan bahwa konten ini tidak bermaksud untuk membuat program komedi, namun mengkritisi kondisi sosial dan politik dengan humor.
\end{abstract}

Kata Kunci: Humor, Satir, Talkshow, Twitter

\section{PENDAHULUAN}

Pandemi Covid-19 akhirnya sampai di Indonesia, diumumkan oleh Presiden Joko Widodo, didampingi Menteri Kesehatan Terawan Agus Putranto pada tanggal 2 Maret
2020. Padahal sebelumnya Terawan mengeluarkan pernyataan-pernyataan yang cukup kontroversial terkait dengan Covid-19 ini di media. Pada tanggal 11 Februari 2020, ia mengatakan bersyukur Covid-19 tak terdeteksi 
di Indonesia, ketika sejumlah pakar dan epidemiolog sudah mempertanyakan kemungkinan virus ini sudah masuk Indonesia. Kemudian pada tanggal 15 Februari 2020, ia kembali menyampaikan pernyataan terkesan menyepelekan saat ditanya harga masker yang melambung, "salahmu sendiri kok beli ya?". Ia menilai orang yang sehat tidak perlu menggunakan masker untuk mengantisipasi virus, yang kemudian pernyataan ini ia ralat sendiri (Ihsanuddin, 2020).

Setelah diumumkan bahwa ada 2 orang WNI yang positif terinfeksi Covid-19, Terawan juga masih memberikan pernyataan yang kontroversial mengenai pandemi ini sehingga menimbulkan pro dan kontra di masyarakat. Hingga akhirnya Presiden Joko Widodo menunjuk Achmad Yurianto sebagai juru bicara pemerintah untuk urusan virus Corona pada tanggal 3 Maret 2020 (Detik, n.d.). Setelah penunjukkan tersebut, Terawan mulai jarang tampil di media, baik wawancara, konferensi pers maupun mengisi acara talkshow di televisi. Pernah satu kali Terawan tampil berbicara di talkshow Mata Najwa yang ditayangkan di Trans7 pada tanggal 5 Februari 2020, sebelum Covid-19 sampai di Indonesia. Setelah itu, Terawan sudah tak terlihat di publik, baik di acara Mata Najwa maupun media-media lain. Ketidakmunculan Terawan di publik menimbulkan tanda tanya, kemanakah dia, dan apa kebijakannya untuk menanggulangi wabah ini.

Sebuah akun Instagram @megatrikania pernah menanyakan kepada Najwa Shihab pada tayangan Mata Najwa di Trans7 pada tgl 10 Juni 2020: "Mbak Nana nitip pertanyaan. Pak Terawan ada dimana ya? Terima kasih", yang dijawab Najwa: "3 bulan PSBB, Mata Najwa hampir tiap minggu mengundang Menteri Kesehatan Pak Terawan tapi belum bersedia hadir di Mata Najwa". Hingga akhirnya pada tgl 28 September 2020, Mata Najwa merilis sebuah video berdurasi 4 menit 22 detik di kanal Youtube Mata Najwa dan Twitter @matanajwa dengan tagar \#MataNajwaMenantiTerawan. Tagar ini menempati posisi ke-2 trending topic Twitter tgl 28 hingga 29 September 2020. Hingga tulisan ini dibuat, 17 Oktober 2020, video ini telah mencapai 4,5 juta views di Youtube dan diunggah ulang oleh beberapa akun Twitter yang terverifikasi.

Hal yang menarik dari video dengan tagar \#MataNajwaMenantiTerawan ini adalah tim Mata Najwa menggunakan humor yang dianggap menyindir Terawan Agus Putranto sebagai Menteri Kesehatan dalam menyampaikan pertanyaan, kritikan dan undangan untuk hadir di studio acara ini. Najwa juga menggunakan kursi yang kosong sebagai ganti absennya Menteri Terawan memenuhi undangan tampil di acara Mata Najwa. Takarir Twitter yang ditampilkan di konten ini, seperti yang tampak pada Gambar 1 yaitu: "Ke mana Menkes Terawan? Kesekian kalinya kami mengundang, inilah kursi dan panggung \#MataNajwa untuk Pak Terawan", yang diakhiri dengan tagar dan tautan menuju ke video di Youtube. Konten tersebut merupakan awal dari utas yang terdiri dari 7 konten. Akhir dari utas tersebut adalah: "Banyak pekerjaan rumah yang harus dilakukan, namun semua bisa diawali dengan kehadiran. Pak Terawan, tempat dan waktu dipersilakan."

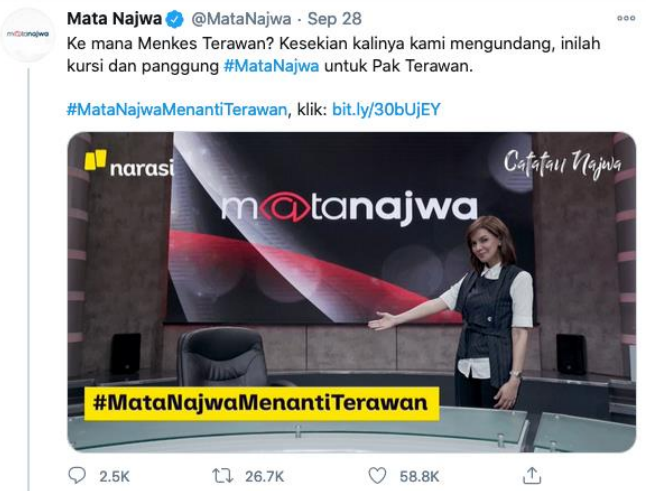

Gambar 1.Cuitan pertama @ MataNajwa pada tagar \#MataNajwaMenantiTerawan (Sumber: Twitter, 2020)

Berbagai respons disampaikan warganet melalui akun Twitter@matanajwa dari mulai mendukung, menyanggah, hingga menampilkan meme yang diambil dari cuplikan video ini. "Mata Najwa seperti menampar wajah (Terawan), namun dengan sarkasme" cuit salah seorang netizen. "Bakar kursi 
kosong! Bagaimana cara biar bisa sarkasme dengan tetap elegan kaya Mbak Najwa" cuit netizen lainnya. Penyanyi sekaligus penulis buku, Fiersa Besari juga ikut berkomentar, "Tapi serius, harus nonton episode Mata Najwa malam ini. Sarkasme yang cukup menohok. Silakan, Kawan-kawan."

Mata Najwa adalah program gelar wicara yang dipandu oleh jurnalis senior, Najwa Shihab yang menghadirkan topik-topik menarik dengan narasumber kelas satu. Program ini awalnya tayang di televisi berita Metro TV, kemudian pindah ke Trans7 (Paputungan et al., 2017). Dari awal siaran pertamanya tahun 2009 hingga tulisan ini dibuat, program ini adalah program yang serius-kecuali saat menghadirkan bintang tamu komedian-biasanya membahas seputar politik, hukum atau ekonomi yang sangat serius. Pemandu acaranya pun terkenal sebagai jurnalis yang serius, apalagi pada saat mencecar narasumbernya dengan pertanyaan-pertanyaan tajam khas wartawan, bahkan senyumpun jarang hadir di bibirnya. Sehingga tagar dan konten dari Mata Najwa ini menarik untuk diteliti karena berdasarkan hal tersebut di atas, Mata Najwa memilih cara pandang humor untuk mempertanyakan kehadiran Menteri Terawan di publik, dibandingkan dengan cara pandang lain yang lebih serius. Tagar dan konten ini pun mendulang respons yang beragam dari warganet yang resah dengan ketidakjelasan informasi mengenai virus ini. Banyak yang mendukung, banyak pula yang menghujat karena menganggap Mata Najwa mencari sensasi belaka. Berbagai wacana humor juga ditampilkan warganet pada tagar \#MataNajwaMenantiTerawan ini.

Video ini pernah diteliti oleh peneliti lain dari sudut pandang wacana kritis seperti yang dilakukan oleh Baehaqi. Hasil dari penelitiannya memperlihatkan bahwa analisis teks mengungkap desakan akan mundurnya Menteri Terawan karena undangan yang tak kunjung berbalas dengan kehadirannya. Pada analisis sosialnya, wacana yang terbentuk oleh Mata Najwa menjadi kuat dalam hal praktik kekuasaan (power) karena Najwa Shihab selaku pembawa acara pada program ini tetap melakukan kegiatan wawancara dengan tidak menghadirkan narasumber (Baehaqi, 2021). Namun, untuk meneliti humor, bukanlah sesuatu yang mudah, karena menurut Ruch dalam Saifudin dkk, belum ada pengukuran selera humor yang ada sejauh ini. Tim peneliti ini juga berpendapat bahwa humor tidak mudah untuk dipahami karena subjektivitas yang dialami berdasarkan pengalaman unik dari setiap kognisi seseorang. Sehingga humor tidak dapat dianggap sebagai sesuatu yang dapat digeneralisir (Saifudin et al., 2019). Untuk itulah, diperlukan penelitian yang dapat mendeskripsikan wacana humor yang terdapat pada konten yang dianggap tidak lucu. Karena menurut budayawan Jaya Suprana, humor tidak (selalu) lucu. Terlepas dari apakah peneliti pro atau kontra akan video ini-maka pertanyaan dari penelitian ini adalah: (1) Bagaimana wacana humor yang terdapat pada konten video di Twitter \#MataNajwaMenantiTerawan berdurasi 4 menit 22 detik ini?; (2) Bagaimana cuitan hingga tercipta wacana humor warganet Twitter saat menanggapi tagar \#MataNajwaMenantiTerawan yang trending ini?; (3) Kenapa Mata Najwa meluncurkan video ini dan bagaimana proses kreatifnya sehingga dapat menghasilkan humor?

Tujuan dari penelitian ini adalah mendeskripsikan wacana humor yang tercipta dari video \#MataNajwaMenantiTerawan dan juga dari cuitan warganet yang menciptakan wacana humor baru di Twitter. Manfaat dari penelitian ini adalah membuat pembaca dan warganet dapat memandang setiap peristiwa dari perspektif humornya, terutama saat berselancar di linimasa Twitter.

\section{METODOLOGI PENELITIAN}

Penelitian ini menggunakan paradigma penelitian konstruksionis, konsentrasi analisis dari paradigma ini adalah bagaimana menemukan realitas atau peristiwa tersebut dikonstruksi dan dengan cara apa konstruksi itu dibentuk (Hasan, 2016). Sehingga penelitian ini menyajikan interpretasi dari konstruksi video yang dibuat oleh tim Mata Najwa dan komentar 
dari pengguna Twitter yang menggunakan tagar \#MataNajwaMenantiTerawan. Penelitian ini berupaya obyektif dan menangkap realitas yang telah dikonstruksi di dalam sebuah teks. Pendekatan penelitian yang digunakan adalah kualitatif deskriptif dengan mengadakan klasifikasi dan penilaian standar norma. Jenis penelitian yang akan digunakan adalah studi kasus, yaitu suatu serangkaian kegiatan ilmiah yang dilakukan secara intensif, terinci dan mendalam tentang suatu program, peristiwa, dan aktivitas, baik pada tingkat perorangan, sekelompok orang, lembaga, atau organisasi untuk memperoleh pengetahuan mendalam tentang peristiwa tersebut (Prof. Dr. H. Mudjia Rahardjo, 2017). Studi kasus, menurut Muhtar, sangat cocok digunakan saat seorang peneliti ingin mengungkap sesuatu dengan bertolak pada pertanyaan "How" atau "Why" (Umrati \& Wijaya, 2020), sebagaimana pertanyaan dari penelitian ini.

Teknik pengumpulan data adalah melalui studi dokumentasi dan wawancara. Penelitian dilakukan dengan menganalisis video dengan judul dan tagar \#MataNajwaMenantiTerawan yang berdurasi 4 menit 22 detik sebagai unit analisis 1 dan komentar dari pengguna Twitter yang berada pada tagar ini menanggapi video yang diunggah oleh Najwa Shihab sebagai unit analisis 2. Strategi penelitian ini juga akan melakukan wawancara mendalam kepada tim Mata Najwa untuk mengetahui mengapa mereka membuat video ini dan bagaimana humor yang digunakan. Penelitian dimulai pada bulan November 2020 dan berakhir di bulan Mei 2021, baik secara daring maupun luring.

\section{HASIL DAN PEMBAHASAN Teknik Humor}

Kehadiran humor seringkali diremehkan bahkan dilupakan orang, dianggap sebagai sesuatu yang tidak serius dan mudah. Padahal, tidak mudah untuk membuat humor, perlu kecerdasan dan keahlian yang khusus. Bahkan, humor banyak sekali teorinya yang dapat ditemukan di berbagai literatur akademik kontemporer. Tiga teori humor yang paling banyak dibicarakan adalah: (1) teori pembebasan yaitu tertawa adalah mekanisme homeostatis dimana ketegangan psikologis berkurang; (2) teori keunggulan yaitu seseorang tertawa karena melihat kemalangan orang lain, merasa lebih superior / unggul dibandingkan orang yang malang tersebut; (3) teori keganjilan yaitu humor timbul saat terjadi keganjilan dan berfokus pada unsur kejutan karena terjadi konflik antara apa yang diharapkan dan apa yang sebenarnya terjadi di humor tersebut. Tiap humor dapat mencakup salah satu teori tersebut, bahkan dapat mencakup ketigatiganya (Sudarmo, 2013).

Humor dikomunikasikan oleh manusia melalui berbagai macam cara dengan berbagai macam tujuan. Bentuk dari humor sendiri dibagi menjadi dua, yaitu humor verbal dan humor non-verbal. Humor verbal ada 8 jenis, yaitu: (1) Deliberate ridicule, dilakukan dengan mengolok-olok orang lain atau sesuatu; (2) Malapropism, tidak mengucapkan sesuatu dengan cara benar namun menggunakan suara yang mirip-mirip dengan cara yang tidak pantas; (3) Spoonerism, perubahan suara dari 2 atau lebih kata sebagai hasil produksi dari ucapan yang lucu (4) Allusion, humor yang bermakna ganda; (5) Satire, cara untuk memadukan kritikan, kekonyolan dan kebodohan melalui ejekan dengan tujuan untuk mengubah atau melakukan reformasi; (6) Parody, imitasi yang lucu; (7) Irony, mengekspresikan makna yang memiliki tendensi kebalikannya; (8) Lapses, humor yang tidak disengaja, misalnya keseleo lidah (Abbas, 2019). Karya lelucon hasil kreasi (lawak, ceramah, pidato, pertunjukan, gambar, tulisan dan segala ekspresi yang dilakukan melalui medium komunikasi antarmanusia) bisa dilacak 'senjata' atau 'jurus' yang menjadi pilihan kreator sebagai alat pengungkapan ekspresinya. Jurus yang sangat khas Indonesia, yaitu Guyon Parikena (Sudarmo, 2020) yaitu menyindir secara halus tanpa melukai hati dari pihak yang dikritik. Pihak yang dikritik tidak sakit hatinya, orang yang mengkritik bebas dalam menyuarakan hatinya (Cahyaningrum, 2018, p.414). Menurut Darminto, guyon parikena isi leluconnya bersifat nakal, agak menyindir tapi 
tidak terlalu tajam, bahkan cenderung sopan. Dilakukan oleh bawahan kepada atasan atau orang yang lebih tua atau yang lebih dihormati atau kepada pihak lain yang belum terlalu akrab. Ada juga yang menjuluki lelucon ini sebagai lelucon persuasif dan berbau feodalisme (Sudarmo, 2020). Guyon parikena menyindir secara halus yang tidak menimbulkan kemarahan yang berkuasa, dan bahkan seperti mengejek diri sendiri walaupun sesungguhnya yang dibidik adalah orang yang tengah berkuasa. Itulah cara yang ditempuh oleh Teater Gandrik untuk melakukan "kritik sosial", terhadap kamuflase kekuasaan Orde Baru, yang meski pun tampak santun dan halus, sesungguhnya sangat represif dan manipulatif (Ciputra Artpreneur, 2019).

Dari semua istilah tersebut di atas, biasanya yang berkaitan dengan humor politik maupun kritik terhadap penguasa yaitu adalah: Satire, Irony, Parody, dan Parikena. Jenis-jenis humor tersebut biasa digunakan di dalam tayangan politik atau pemerintahan dan juga meme politik yang banyak digunakan di dalam media sosial, terutama Twitter. Penelitian ini juga akan membahas mengenai sarkasme (dan bedanya dengan satire), karena beberapa komentar dari warganet mengatakan bahwa video Najwa tersebut termasuk sarkasme tingkat tinggi. Menurut Tsakona \& Popa, banyaknya humor yang bertemakan politik karena humor merupakan salah satu cara untuk memahami isu politik. Humor sering meningkatkan keefektifan pesan politik. Humor politik dapat disusun sebagai suatu rangkaian kesatuan, mulai dari hal-hal yang mendukung dan bersifat lembut sampai pada hal-hal yang merusak dan subversif (Tsakona \& Popa, 2011).

Tidak banyak buku atau jurnal yang membahas mengenai satire dalam gelar wicara di televisi. Bahkan satire atau satir didefinisikan berbeda-beda di beberapa sumber. Satire merupakan salah satu dari genre humor, walaupun tidak selalu memproduksi hasil dari humor, namun tujuan utamanya adalah mengungkap kegagalan seseorang, institusi atau masyarakat dengan mengeksposnya dengan cara yang olokan dan cemoohan, namun membawa nilai moral (Tesnohlidkova, 2021). Konteks yang biasa digunakan dalam satir adalah politik kontemporer dan isu-isu aktuil lainnya. Ada dua hal penting pada satir: (1) Mengolok-olok seseorang, ide atau institusi, (2) Tujuannya bukan hanya untuk menghibur, tetapi juga untuk menginformasikan atau membuat orang berpikir (Literary Devices, n.d.).

Satire dikenal sebagai bentuk tertua dari komentar sosial. Untuk banyak orang, ketidakadilan dan masalah dalam masyarakat mereka terlalu besar untuk dikonfrontasi secara langsung - bahkan kadang-kadang sulit untuk mengetahui mulainya dari mana. Jadi salah satu pendekatannya adalah dengan komedi. Dengan menertawakan sesuatu, kita akan mengakui realitas yang terjadi, dan tidak menyangkal bahwa hal tersebut menguasai emosi kita. Satir juga membuat orang lebih menaruh perhatian pada isu sosial ketika mereka mungkin akan mengabaikannya. Kaum penyindir sengaja memegang sebuah cermin yang merefleksikan cacat dari sebuah masyarakat, sehingga membantu masyarakat untuk berpikir kritis mengenai sesuatu yang mungkin biasanya mereka terima begitu saja.

Satire biasanya disampaikan dalam bentuk ironi, sarkasme atau parodi. Parodi adalah melakukan imitasi yang mengibaratkan sesuatu dengan tujuan untuk menimbulkan tawa dan mengungkap kekuasaan dan otoritas pada siapa mereka dan bagaimana mereka bertindak (Sinclair, 2020). Parodi adalah bentuk dari imitasi atau peniruan yang gaya dan perangai dari sejumlah penulis terkenal yang diguraukan. Saat meniru gaya, sebaiknya menggunakan teknik yang jenaka untuk meninggikan humornya. Parodi mungkin adalah satu teknik yang terkuat dan paling banyak digunakan untuk menghasilkan humor, dan beberapa teori komedi mengklaim bahwa batang dari seluruh humor berasal dari parodi (Berger, 2017). Arwah Setiawan, pakar humor dan pendiri Lembaga Humor Indonesia, pada September 1993 di Majalah Humor, menulis bahwa parodi yang efektif haruslah didasarkan 
pada versi asli yang sudah diketahui dengan baik (familiar) bagi masyarakat luas (Setiawan, 2020). Perbedaan antara parodi dan satir, tidaklah mudah untuk diberi garis tegas, namun biasanya diasumsikan bahwa satir memiliki elemen yang agresif dan kritis yang tidak selalu ada di parodi (Simpson \& Bousfield, 2017)

Sarcasm atau sarkasme menurut Colston dalam bukunya Attardo, adalah bentuk dari ironi verbal yang sangat kuat hubungannya dengan ekspresi yang negatif. Sarkasme umumnya dianggap keji, jahat atau hanya bentuk negatif dari ironi verbal, digunakan pada situasi untuk mempertegas ekspresi negatif secara langsung, atau kritikan yang tidak jelas bentuknya (Simpson \& Bousfield, 2017).

\section{Wacana Humor pada Video Durasi 4 menit 22 detik \#MataNajwaMenantiTerawan}

Cerita dibangun mulai detik ke 00.0000.49 , video dibuka dengan musik khas dari acara Mata Najwa, yang mengesankan seperti situasi dalam keadaan gawat, dengan kamera yang menyapu studio dengan puluhan kursi penonton yang kosong, yang biasanya terisi penuh. Visual mendeskripsikan bahwa karena pandemi, maka acara ini meniadakan penonton di studio untuk mencegah penularan Covid-19. Kamera lalu mengarah ke Najwa Shihab yang juga menghadap ke kamera dan membuka acara informasi bahwa Mata Najwa mengundang Menteri Kesehatan Terawan Agus Putranto untuk memberikan penjelasan mengenai situasi pandemi yang belum mereda dan terkendali. Dijelaskan pula bahwa Terawan (sebagai Menteri Kesehatan) yang memiliki wewenang, akses anggaran dan pemberi arahan, seharusnya beliau yang paling gencar memperjuangkan kepentingan kesehatan. Namun, kesekian kalinya Mata Najwa mengundang, beliau tidak pernah datang. Kemudian Najwa berkata: "Kesekian kalinya kami mengundang, inilah kursi dan panggung Mata Najwa untuk Menteri Terawan".

Pernyataan ini membangun ekspektasi penonton bahwa Terawan akhirnya datang pada episode kali ini. Ekspektasi yang dibangun ini, dalam humor dan stand-up comedy disebut dengan set-up, yaitu bagian pertama dari sebuah lelucon yang berisi premis, topik dan sikap si komika terhadap suatu topik. Set-up bertujuan untuk membangun asumsi di pikiran penonton (Pragiwaksono \& Fakhri, 2020). Dalam hal ini, Najwa membangun asumsi penonton bahwa tamu yang ditunggu-tunggu tersebut akan hadir seperti tamu-tamu lainnya. Episode-episode Mata Najwa sebelumnya yang menghadirkan bintang tamu, pasti yang bersangkutan akan hadir.

Namun, ekspektasi tersebut kemudian dipatahkan dengan adegan selanjutnya (00.5100.58) yaitu kamera menyapu studio, kemudian close-up ke kursi kosong yang merupakan punchline dari set-up yang telah dibangun tadi. Punchline adalah bagian kedua dari suatu lelucon yang berisi pematahan asumsi atau twist yang sudah dibangun oleh set-up (Pragiwaksono \& Fakhri, 2020). Keganjilan yang timbul dari kursi yang biasanya diduduki oleh bintang tamu, kali itu kosong, yang menandakan tamunya absen tetapi acara tetap berlangsung, sudah merupakan humor seperti yang tertera dalam incongruity theory karena penonton dikejutkan oleh kursi kosong yang tidak lazim ada di acara wicara di televisi. Asumsi penonton cukup dipatahkan dengan punchline non-verbal yaitu arah kamera yang aneh atau tidak biasa, diperkuat dengan musik yang dramatis.

Humor non-verbal selanjutnya, ada pada adegan saat Najwa mulai bertanya kenapa menghilang dan minim muncul di depan publik untuk memberikan penjelasan selama pandemi. Kemudian kamera mengambil gambar ke kursi kosong tersebut dan Najwa, seolah-olah ia bertanya kepada Menteri Terawan yang duduk di situ, yang pada kenyataannya tidak ada siapasiapa. Adegan ini termasuk ke dalam humor karena tidak lazim bila pembawa acara bertanya kepada benda yang pasti tidak bisa menjawab, namun ia bersikeras tetap saja berbicara. Kamera juga berkali-kali menampilkan kursi kosong tersebut, seperti layaknya siapa pun yang duduk di kursi tersebut sedang menjawab pertanyaan Najwa, menambah humor nonverbal video ini. Hingga akhir video pada 
04.22, Menteri Terawan tetap tidak hadir dan kursi itu tetap kosong.

Selain non-verbal, humor juga hadir dalam bentuk verbal. Najwa bertanya hal-hal yang juga ingin ditanyakan oleh masyarakat kepada Terawan. Pertanyaan dari Najwa: "Mengapa menghilang pak? Anda minim sekali muncul di depan publik, memberi penjelasan selama pandemi". Pertanyaan tersebut walaupun fakta, namun diksi yang digunakan jenaka karena menggunakan kata 'menghilang' yang memiliki arti 'melenyapkan diri' atau 'tidak memperlihatkan diri', yang juga persamaan kata untuk 'gaib' seperti makhluk halus, alihalih bertanya misalnya "kenapa tidak muncul di publik pak?". Diksi unik ini termasuk ke dalam humor karena superiority theory dari Najwa sebagai pembawa acara dan pewawancara.

Pertanyaan dilanjutkan dengan sindiran Najwa: "Rasanya menteri kesehatan yang paling low profile di seluruh dunia selama wabah ini hanya Menteri Kesehatan Republik Indonesia. Atau kehadiran menteri kesehatan di muka publik memang anda rasa tidak terlalu penting?". Sindiran Najwa ini merupakan kiasan ironi, yaitu suatu acuan yang ingin mengatakan sesuatu dengan makna atau maksud berlainan dari apa yang terkandung dalam rangkaian kata-katanya. Ironi akan berhasil kalau khalayak juga sadar maksud yang disembunyikan di balik rangkaian katakatanya (Keraf, 2016). Najwa menyatakan Menteri Kesehatan RI sebagai Menteri yang paling low profile namun menanyakan kehadiran di muka publik yang dirasa tidak terlalu penting (yang bertentangan dengan low profile), sehingga maksudnya menjadi berlainan. Ironi ini termasuk ke dalam guyon Parikena yang menyindir dengan cara yang tidak menghina, bahkan menaikkan derajat, namun khalayak tetap sadar bahwa maksudnya adalah menyindir karena kehadiran orang yang paling berwenang menjawab pertanyaan publik saat krisis adalah penting.

Sarkasme juga ditemukan dalam penyataan Najwa yang mengungkap Menteri-menteri Kesehatan di seluruh dunia yang mundur saat tidak dapat menangani pandemi di negaranya.
Penyataan ini disusul dengan pertanyaan apakah penanganan di Indonesia lebih baik dari negara yang MenKesnya mundur. Selain itu desakan Presiden RI dan publik meminta Menteri Terawan untuk mundur saja, dengan jelas Najwa bertanya:" ... siap mundur pak?". Sarkasme lebih kasar dari ironi, bisa bersifat ironis, bisa juga tidak, tapi yang jelas, gaya ini akan menyakiti hati dan kurang enak didengar (Keraf, 2016). Di negara yang menganut adat ketimuran, bertanya kepada penguasa apakah ia siap turun dari jabatan seringkali mengagetkan yang mendengar, dan unsur surprise atau mengagetkan itu adalah unsur yang terdapat di dalam humor.

Video ditutup dengan Najwa yang berbicara ke kamera, seolah-olah sedang berkomunikasi dan menyapa Terawan:"Pak Terawan, itu hanya sebagian dari pertanyaan yang bukan datang hanya dari saya tapi juga kami kumpulkan dari publik untuk anda, Menteri Kesehatan. Kami tau, tak ada yang dapat menyelesaikan persoalan pandemik ini sendirian. Tapi kami berharap Anda setidaknya bersedia untuk memberi gambaran. Menteri Kesehatan, Terawan Agus Putranto, waktu dan tempat, dipersilakan...". Najwa mengkritik dengan satir bahwa Terawan diharapkan hadir untuk memberikan gambaran akan sulitnya menangani pandemi ini. Untuk itu, Mata Najwa menyediakan waktu dan tempat di acara ini, jika akhirnya Terawan bersedia hadir. Menurut Arwah Setiawan pada 11 Juli 1994 di majalah Sarinah mengatakan bahwa humor yang mengkritik, atau kritik lewat humor, meskipun tidak menyajikan pemecahan masalah secara langsung namun dapat memberi peringatan akan kesalahan objek kritik, tidak mendatangkan kekerasan, dan dapat melegakan masyarakat yang terwakili oleh kritik tersebut (Ryadi, 2020). Sehingga penonton pun merasa terwakili karena pertanyaan dan pernyataannya dinyatakan oleh Najwa secara terbuka tanpa kekerasan.

Situasi dan pertanyaan-pertanyaan yang diajukan Najwa di video ini juga bisa digambarkan seperti kisi-kisi situasi dan pertanyaan yang akan diajukan apabila Menteri 
Kesehatan hadir. Pertanyaan tersebut juga diakui Najwa merupakan pertanyaan dari masyarakat yang dikumpulkan dari berbagai sumber, yang mengesankan acara Mata Najwa merupakan perwakilan isi hati masyarakat. Perubahan kualitatif telah terjadi pada humor politik terkini ke arah penggunaan dari advocacy satire, yaitu penggunaan humor politik untuk mengambil tindakan atas nama masyarakat yang dirugikan, memperkuat suara mereka dengan campur tangan langsung pada urusan publik. Satir sengaja digunakan di sini sebagai penggunaan humor untuk menargetkan dan menegur substansi dari penguasa (Waisanen, 2018)

\section{Wacana Humor Warganet Twitter Terkait Video \#MataNajwaMenantiTerawan}

Dari total ribuan cuitan di dalam tagar ini di Twitter, hanya dipilihkan 14 cuitan yang mengandung humor, yang seolah-olah merespons video yang dibuat oleh Narasi TV ini. Cuitan yang mengandung humor ini terpilih karena terdapat keganjilan dan kejutan pada muatan kontennya sesuai dengan teori keganjilan pada humor. Keganjilan meliputi: absurditas, keanehan, ambiguitas (makna ganda), ketidakmungkinan, ketidaksesuaian, ketidakrelevanan, dan ketidakterdugaan (Westacott, 2012) baik dalam konteks, teks maupun visualnya. Cuitan yang mengandung hinaan ataupun hujatan, tidak dianalisis untuk tetap fokus kepada humor yang tercipta oleh tagar dan video ini.

Konten pertama yaitu cuitan dari @MataNajwa dan juga @ pelajarlogis tgl 29 September 2020 yaitu: "Whenever you're ready, whenever you're ready " yang mengambil penggalan lagu Surrender dari Natalie Taylor yang artinya: "kapanpun kamu siap, kapanpun kamu siap". Cuitan juga disertai dengan video Terawan yang sedang diwawancarai oleh Narasi TV tgl 6 Februari 2020, disertai dengan pernyataannya yaitu: "Saya lebih senang kalo sering dipanggil Mata Najwa ini sehingga bisa balik ke sini" yang kemudian pernyataan ini diulang 3 kali seolaholah ingin mempertanyakan pernyataannya yang tidak sesuai dengan kenyataan. Kemudian pernyataan tersebut ditutup dengan lagu Surrender dari Natalie Taylor dengan lirik yang sama dengan takarir. Analisis dari humor ini adalah satir yang dibuat Mata Najwa dengan mengangkat ucapan Terawan sendiri yang senang hadir di acara ini, namun tidak menjadi kenyataan hingga tulisan ini dibuat. Kemudian disindir dengan lagu Surrender (lirik: kapanpun kamu siap), seolah-olah Najwa mempersiapkan tempat dan waktu kapan pun Terawan siap tampil untuk diwawancara.

Dari video \#MataNajwaMenantiTerawan, kemudian lahir wacana humor baru berupa tangkapan layar yang dijadikan meme. Meme itu sendiri adalah sekelompok materi digital yang menyebarkan konten umum dalam berbagai karakteristik, bentuk, dan sikap, yang diciptakan berdasarkan kesadaran bersama, disirkulasikan, diimitasi, dan ditransformasikan melalui internet oleh banyak orang (Limor Shifman, 2014). Tangkapan layer yang paling banyak dijadikan meme yaitu gambar kursi kosong dan Najwa yang tampak sedang menunggu jawaban, seperti tampak di Gambar 2. Konten meme dari @ semoothq: (1) Najwa dilabeli "Mba Bos" dan kursi dilabeli "Aku" dengan keterangan gambar: "SELESAI MEETING Jam Maksi (makan siang). Aku sama temen-temen, 1 DETIK KEMUDIAN". Kontekstualisasi dari konten ini adalah dengan memparodikan video Mata Najwa dengan situasi di kantor yang sering mengambil waktu makan siang untuk rapat, sehingga kelucuan muncul 1 detik setelah rapat, peserta rapat sudah menghilang meninggalkan kursi kosong, walaupun pimpinan masih duduk di ruangan. Seolah peserta rapat tidak peduli dengan rapat tersebut, yang terpenting adalah mengisi perut 1 detik setelah rapat berakhir; (2) Najwa seolaholah sedang berharap yang dilabeli "Aku" dan kursi kosong dilabeli "HRD (Human Resources Department)" dengan tulisan "Jadi gimana pak, cuti saya diapprove kan?". Analisis humor dari meme ini yaitu pegawai yang berharap cuti di saat beban pekerjaan sedang tinggi, meminta cutinya disetujui, namun bagian HRD sebagai divisi yang memberikan persetujuan cuti 
seringkali absen (seperti MenKes) dalam situasi tersebut.

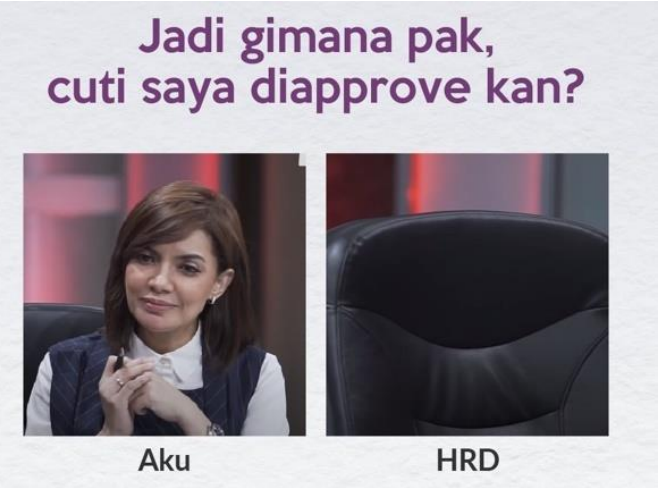

Gambar 2. Cuitan akun @ semoothq pada tagar \#MataNajwaMenantiTerawan (Sumber: Twitter, 2020)

Meme terbanyak diproduksi dari foto cuplikan dari video yang menyorot pada kursi kosong dan Najwa membelakangi kamera dengan tangan terlipat di bawah dagu yang khas Najwa pada saat bertanya kepada narasumbernya. Kemudian kursi kosong ini diisi oleh tempelan foto tokoh ataupun nontokoh seakan-akan merekalah yang sedang diwawancarai oleh Najwa. Meme ini diberikan ataupun komponen lainnya untuk memperkuat konteks. Sebagai contoh, cuitan dari @yoshiroemillio dengan tulisan "much better" yang artinya adalah jauh lebih baik dengan konteks gambar Najwa dari belakang dan kursi kosong yang 'diduduki' oleh Impostor dari game Among Us yang sedang digandrungi anak muda. Menurut detik.com, Impostor adalah karakter penipu, dia berpura-pura menjadi karakter Crewmate yang tugasnya memperbaiki kerusakan di luar angkasa (Ramadhanny, 2020). Dalam konten ini, kelucuan terjadi dengan memparodikan Terawan secara absurd dengan Impostor yang antagonis karena karakter penipu yang berpurapura hendak memperbaiki kerusakan. Bahkan, pemilik akun menambahkan dengan tulisan "jauh lebih baik" yang dimaksudkan Impostor lebih baik dibandingkan Terawan, karena Impostor membuat game Among Us menjadi seru. Konteks meme yang sama juga dicuit oleh @ nuragamoh namun diganti dengan foto dirinya sendiri yang sedang mengangkat tangan ke belakang kepala dengan mata terpejam seolah-olah sedang tidur. Dengan takarir "Mewakili Pak Terawan untuk rebahan di kursi $\sim$ ia dengan satir seolah-olah ingin mengatakan bahwa Terawan selama ini hanya tidur saja sehingga tidak melakukan pekerjaannya. Analisis humornya yaitu pemilik akun seolah-olah ingin mewakili Terawan untuk duduk di kursi namun dengan posisi yang sama yaitu rebah, dan tetap tidak menjawab pertanyaan Najwa.

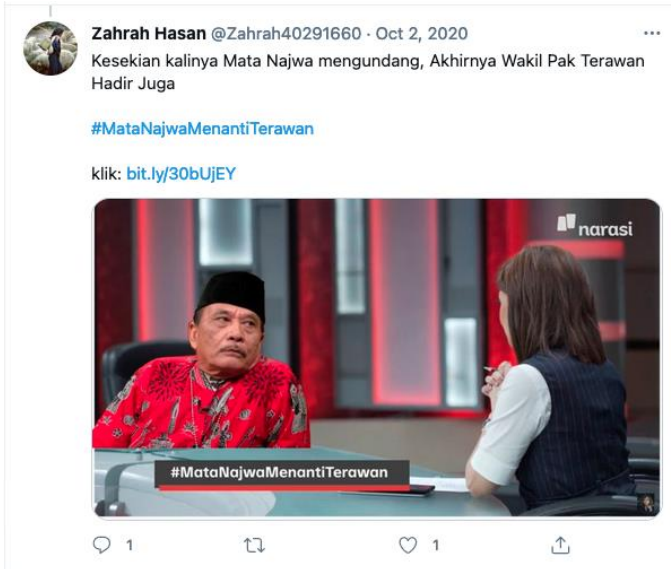

Gambar 3. Cuitan akun@Zahrah40291660 pada tagar \#MataNajwaMenantiTerawan (Sumber:

Twitter, 2020)

Kelucuan lain dari meme yang sama, dicuit oleh@Zahrah40291660 terlihat pada Gambar 3 yang menempelkan foto Bolot, pelawak senior dari Betawi yang terkenal dengan kekurangannya dalam mendengar omongan dari lawan bicaranya. Ia hanya dapat jelas mendengar pembicaraan orang lain bila berkaitan dengan hal-hal yang ia senangi, seperti uang, perempuan dan makanan. Di konten ini Bolot dibuat seolah-olah yang sedang diwawancarai Najwa dengan takarir "Kesekian kalinya Mata Najwa mengundang, Akhirnya Wakil Pak Terawan Hadir Juga". Kontekstual dari konten ini adalah Bolot dianggap sebagai wakil Terawan, yang juga terkenal tidak dapat mendengar atau salah menangkap maksud lawan bicaranya. Secara satir pemilik akun ingin mengungkapkan bahwa wakilnya pun tidak dapat mendengar aspirasi rakyat. Bolot yang saat tampil 
seringkali dengan seragam safari ataupun batik layaknya pejabat di Indonesia, diungkapkan oleh@Adriandhy memberikan gambaran dalam bentuk satir bagaimana pejabat pemerintah tidak pernah mendengar (budeg) suara rakyat selain pembicaraan tentang uang dan perempuan (Habib, 2020).

Berbeda dengan cuitan lainnya, cuitan dari @ V4aVendetta justru menampilkan Terawan seolah-olah hadir di acara tersebut dengan tersenyum. Kontekstual pemilik akun seolaholah 'meledek' Najwa dengan takarir "I am sorry mba@MataNajwa" yang seperti menyampaikan bahwa mohon maaf (jika selama ini tidak hadir) ternyata Terawan akhirnya 'hadir' walaupun hanya tempelan.

Cuitan bersambung dari @margianta dengan bahasa Inggris yang bunyinya: "Jurnalis Indonesia@NajwaShihab mewawancarai kursi kosong (alih-alih Kementerian Kesehatan yang ketakutan diundang) sebagai peristiwa yang ikonik tapi ironis dari pemerintah yang transparan dan akuntabel". Kemudian cuitan ini dibalas oleh @AdieuAmourr yang juga berbahasa Inggris yang berbunyi: "Kementerian Kesehatan Indonesia sangat transparan, kita bahkan tidak dapat melihatnya di publik (emoji kera sedang menutup wajahnya)". Kedua cuitan ini mengandung humor karena bersifat ironi dan satir. Analisis humor dari cuitan pertama yaitu ironi dari pemerintah yang dianggap transparan dan akuntabel namun tidak mampu mengkomunikasikan kebijakan yang telah diambil kepada publik secara transparan dan akuntabel. Pemilik akun juga menganggap apa yang dilakukan Mata Najwa dengan kursi kosongnya adalah kejadian yang ikonik. Analisis humor cuitan kedua yaitu KemenKes RI yang sangat transparan sehingga (saking) transparannya hingga tembus pandang dan tidak kelihatan. Pemilik akun melebih-lebihkan atau exaggerate kata transparan. Exaggeration sendiri berhubungan dengan ironi dan dapat membuat ironi lebih terlihat jelas, karena exaggeration adalah interpretasi yang ekstrim mengenai sebuah kenyataan atau bisa juga hal yang tidak nyata. Exaggeration juga biasa digunakan dalam satir dan parodi untuk mencapai efek komunikasi tertentu (Kreuz \& Riordan, 2014).

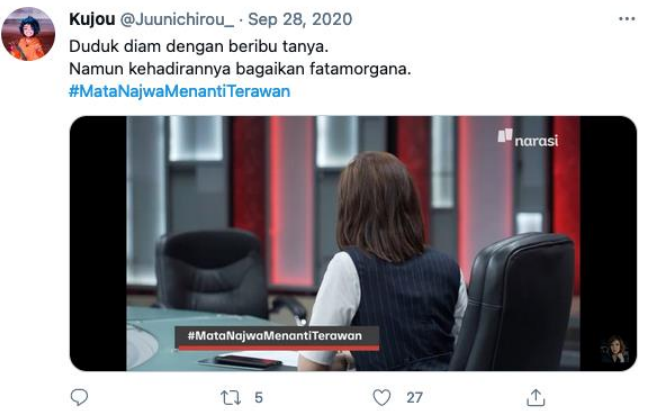

Gambar 4. Cuitan akun @Juunuchirou_pada tagar \#MataNajwaMenantiTerawan (Sumber: Twitter, 2020)

Cuitan lain dari @Juunuchirou_pada Gambar 4 dengan foto yang sama dengan @ yoshiroemillio namun kursi tidak terisi oleh apapun. Ia menambahkan tulisan: "Duduk diam dengan beribu tanya. Namun kehadirannya bagaikan fatamorgana". Fatamorgana adalah pembiasan cahaya melalui kepadatan yang berbeda, sehingga bisa membuat sesuatu yang tidak ada menjadi ada (Setiawan \& Ratyaningrum, 2018). Humor yang hadir dari cuitan ini adalah menganalogikan kehadiran Terawan dengan fatamorgana yang tidak ada namun seolah ada. Analogi adalah membandingkan dengan sesuatu. Analogi sendiri tidak lucu, maka ia harus dikombinasikan dengan teknik humor lainnya seperti exaggeration agar bisa menimbulkan kelucuan (Berger, 2017).

Cuitan ini juga diperkuat oleh @MhdIlhamSaputra yang mencuit: "The Invisible Man" pleaseeee welcome Pak terawaaaan 歌, Ia memetaforakan Terawan dengan manusia gaib / tidak terlihat atau bahkan seperti manusia yang dapat menghilangkan diri. Metafora adalah semacam analogi yang membandingkan dua hal secara langsung, tetapi dalam bentuk yang singkat dan tidak menggunakan kata: seperti, bak, bagai, dan sebagainya (Keraf, 2016). Kedua cuitan ini seolah dijawab oleh cuitan @yaelah_sa yang juga menggunakan Bahasa Inggris dengan 
bunyi: "Tapi bukan ini transparansi yang kita inginkan, Pak... kenapa Anda tanggapi dengan serius $ح$ Sarkasme adalah yang terbaik!! Maju terus, Mbak Nana O" Kontekstual dari cuitan ini ialah ia menganggap video MataNajwa ini adalah sarkasme, sedangkan sarkasme adalah gaya bahasa yang mengandung celaan bahkan menjadi hinaan yang kurang enak didengar oleh lawan tutur. Sehingga kedua cuitan tersebut di atas tidaklah disebut dengan sarkasme, namun lebih ke satir dengan analogi dan metafora.

Cuitan lain berasal dari @ frequency200hz yang memparodikan kartun anak-anak Dora The Explorer yang ceritanya sang tokoh mengajak penonton untuk mencari bendabenda yang hilang. Tangkapan layar dimodifikasi dengan menempelkan Terawan di atas layar besar di atas Najwa, seolah-olah ia sedang bersembunyi namun sedang mengintip. Takarir dari konten dan gambar yaitu "Ayo kita bantu Mba Nana mencari Mentri Pak Terawan!", “Apakah kalian melihat Pak Terawan berada?", "Dimana?". Tagarnya pun ikut diparodikan menjadi \#MataNajwaTheExplorer. Kontekstual dari cuitan ini adalah tokoh Dora The Explorer yang sangat disukai anak-anak karena petualangan mencari jalan keluar dari setiap rintangan, mencari benda yang dicuri oleh Swiper dan lain-lain. Najwa diparodikan menjadi Dora The Explorer dan Terawan diparodikan menjadi Swiper, tokoh jahat yang selalu mencuri apa yang bernilai penting dan berarti bagi orang lain, serta berusaha menggagalkan petualangan sampai ke tujuan dengan berbagai cara (Abdullah Alaiyed, 2020). Sehingga analisis humor cuitan ini adalah warganet diminta oleh Najwa untuk ikut mencari Terawan seperti Dora yang mencari Swiper.

Bahkan, ada warganet @amasna yang memparodikan cuitan dari @KemenkesRI yang seolah-olah mempertanyakan kehadiran Terawan. Kontekstual awalnya, @KemenkesRI mencuit "Tahukah kamu? Setiap tanggal 28 September diperingati sebagai Hari Rabies Sedunia (World Rabies Day). Kampanye global ini diselenggarakan untuk meningkatkan kesadaran tentang dampak rabies pada manusia
\& hewan serta meningkatkan upaya pencegahan \& pengendalian rabies di dunia". Dengan awal kalimat yang sama, kemudian diparodikan menjadi "Tahukah kamu? Menteri Kesehatan Terawan Agus Putranto beberapa kali diundang untuk hadir di @ MataNajwa. tapi sampai saat ini belum ada respons sampai ada episode \#MataNajwaMenantiTerawan dengan @NajwaShihab mewawancarai kursi kosong?". Parodi politik ini merupakan salah satu aspek penting dalam bahasa politik. Humor politik bisa berupa lelucon, komedi, satir yang berisi berisi tentang suatu rezim pemerintahan, sistem dan institusi politik, para politisi atau para pembuat kebijakan. Humor politik kadangkadang dapat membantu para individu untuk mencurahkan kekecewaan terhadap institusi politik atau para politisi (Lesmana, 2014).

Cuitan dari @yogaardy07 pada Gambar 5, juga unik karena mengambil dari lelucon semacam tebak-tebakan "knock knock, who's there?" yang populer di Amerika Serikat, Inggris, Perancis dan lain-lain. Ketika memulai lelucon ini, kita akan mengatakan "knock knock", dan kemudian dibalas oleh lawan bicara kita dengan "Who's there?" kemudian dimulai leluconnya yang biasanya seputar pelesetan atau juga makna ganda (Martha22, 2014). Analisis humor dari cuitan ini adalah pemilik akun memelesetkan Terawan dari cloudest yang kira-kira artinya adalah ter-awan. Kemudian setelah jelas bahwa yang mengetuk adalah Terawan, kemudian lawan bicaranya berkata,"Ooo silakan duduk pak.. sudah lama tidak bertemu", yang menyindir dengan satir Terawan yang sudah lama tidak terlihat di hadapan publik.

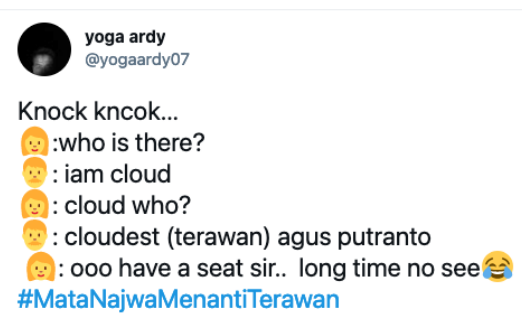

Gambar 5. Cuitan akun @yogaardy07 pada tagar \#MataNajwaMenantiTerawan (Sumber: Twitter, 2020) 


\section{SIMPULAN}

Berdasarkan hasil analisis dari video dan wawancara dengan eksekutif produser Narasi TV yang memproduksi video \#MataNajwaMenantiTerawan terlihat bahwa konten ini tidak bermaksud untuk membuat program komedi, namun mengkritisi kondisi sosial dan politik dengan humor. Kritik yang disampaikan dengan humor dapat lebih mudah diterima oleh publik, bahkan bisa viral secara organik. Bahkan dalam kasus yang diteliti ini, dapat menciptakan wacana humor-humor baru yang segar yang dapat melepaskan ketegangan. Bagaimanapun, Mata Najwa adalah produk gelar wicara yang menyajikan wicara atau pembicaraan dan juga sekaligus hiburan, sehingga hiburan dalam bentuk humor adalah pilihan yang tepat, tetapi juga sekaligus dapat digunakan untuk mengkritisi pemerintah. Di tengah situasi di mana kritikan tidak dapat diekspresikan secara langsung, maka lelucon mengenai pemerintah menjadi sarana untuk mengkritisi. Ditambahkan oleh Louis Rubin, humor muncul karena ada kesenjangan antara ekspektasi yang ideal (akan sesuatu) dengan kenyataan / fakta yang terjadi (Westacott, 2012)

Dalam menjawab realitas ini, wacana humor dalam bentuk satir hadir sebagai pilihan yang menyajikan kritik dengan format dan gaya humor yang beragam. Gaya humor disampaikan dalam bentuk parikena (dalam bentuk yang paling halus), parodi, ironi, hingga sarkasme yang paling kasar. Semua gaya humor ini dapat ditemukan di video \#MataNajwaMenantiTerawan sampai dengan konten yang dibuat oleh warganet di tagar tersebut. Format yang disajikan di Twitter dengan tagar tersebut banyak menggunakan meme, sebagai budaya baru yang banyak disukai Milenial dan generasi $\mathrm{Z}$ sebagai pengguna Twitter dalam ranah politik sebagai bentuk perlawanan politik (Dodalwa, 2019). Dalam fungsinya sebagai penyampai ide, gagasan, sikap dan wacana, meme lazim disampaikan dalam konteks komunikasi nonserius, informal atau bahkan humor (L Shifman et al., 2014). Cara berkomunikasi non-serius, informal dan humor dapat menyebar sangat cepat melalui jaringan internet, seperti virus yang dapat menyebar dengan cepat menjangkit banyak orang dalam waktu yang cepat / viral (L Shifman et al., 2014) bahkan dapat menjadi trending topic di media sosial. Sehingga hasil dari penelitian ini diharapkan dapat memberikan kontribusi dalam pengembangan ilmu, khususnya di bidang komunikasi yang berkaitan dengan humor.

\section{DAFTAR PUSTAKA}

Abbas, N. F. (2019). Humor in TV Talk Shows. International Journal of English Linguistics, $\quad 9(3), \quad 136$. https://doi.org/10.5539/ijel.v9n3p136

Abdullah Alaiyed, M. (2020). The Functions of Code-switching in the Interaction of the Cartoon Characters in Dora the Explorer. Arab World English Journal, 11(3), 260 275. https://doi.org/10.24093/awej/vol11no3.1 6

Baehaqi, I. (2021). Analisis Wacana Kritis Terhadap Episode "Mata Najwa Menanti Terawan" di Trans7. Institut Agama Islam Negeri Purwokerto.

Berger, A. A. (2017). An Anatomy of Humor. In Routledge (1st ed.). Routledge.

Bramasta, D. B. (2020). Tanggapan Dewan Pers soal Laporan Kursi Kosong Najwa Shihab. Kompas.Com. https://www.kompas.com/tren/read/2020/ 10/07/130500865/tanggapan-dewan-perssoal-laporan-kursi-kosong-najwashihab? page $=$ all

Cahyaningrum, D. (2018). Kritik Sosial Dalam Naskah Teater Gandrik Yogyakarta Terhadap Orde Baru Tahun 1983-1998 Avatara, e-Journal Pendidikan Sejarah. 6(2), 410-415.

Ciputra Artpreneur. (2019). https://www.ciputraartpreneur.com/events /detail/para-pensiunan

Detik. (n.d.). Detik.com. Detik.Com. https://news.detik.com/berita/d4937063/bahagia-terawan-teori-terbukticorona-penyakit-yang-akan-sembuh- 
sendiri

Dewi, R. K. (2020). Wawancara Kursi Kosong Najwa Bukan Hal Baru, Ini Kejadian Sebelumnya. Kompas.Com.

Dodalwa, M. C. (2019). " Satir" Antara Kritik Dan Selebrasi (Analisis Reaksi Warganet Terhadap Permohonan Maaf Ratna Sarumpaet). Jurnal PIKMA: Publikasi Ilmu Komunikasi Media Dan Cinema, 2, 45-57.

https://jurnal.amikom.ac.id/index.php/pik ma/article/view/395

Fatmawati, K., Zuthfiyah, R., \& Kafa, R. A. (2020). Demokrasi Dalam Penggunaan Media Sosial ( Studi Kasus Postingan di Twitter Tentang Anggaran Lem Aibon Pemerintah Provinsi DKI Jakarta ). 4(1), 14-25.

Fisher, A. (2019). Spokesperson Endures Empty Chair Humiliation. Media First.

Gustomy, R. (2020). Pandemi ke Infodemi: Polarisasi Politik dalam Wacana Covid-19 Pengguna Twitter. JIIP: Jurnal Ilmiah Ilmu Pemerintahan, 5 . https://doi.org/10.14710/jiip.v5i2.8781

Habib, T. (2020). Balas Unggahan Selebtwit, Warganet Beberkan Fakta Menarik tentang Komedi Malih dan Bolot. Akurat.Co. https://akurat.co/balasunggahan-selebtwit-warganet-beberkanfakta-menarik-tentang-komedi-malih-danbolot

Hasan, K. (2016). Beberapa Metode Penelitian Komunikasi Politik. Jurnal Komunikasi, 2, $1-13$. https://repository.unimal.ac.id/2268/1/BE berapa Metode Dalam Penelitian Komunikasi Politik.pdf

Ihsanuddin. (2020). Kompas.com. Kompas.Com.

https://nasional.kompas.com/read/2020/09 /29/16290701/pernyataan-kontroversialmenkes-terawan-di-awal-pandemi-covid19 ?page $=$ all

Juditha, C. (2015). Fenomena Trending Topic di Twitter: Analisis Wacana Twit \#savehajilulung. Jurnal Penelitian Komunikasi Dan Pembangunan, 16(2),
$138-154$.

Keraf, G. (2016). Diksi dan Gaya Bahasa (21st ed.). Gramedia Pustaka Utama.

Kreuz, R. J., \& Riordan, M. A. (2014). Exaggeration. In S. Attardo (Ed.), Encyclopedia of Humor Studies (p. 223). Sage Publication.

Lesmana, M. (2014). Teks-teks Humor Politik di Indonesia: Sekedar Hiburan atau Sekaligus Kritikan? Journal Susurgalur: Jurnal Kajian Sejarah Dan Pendidikan Sejarah, 2(1), 91-100.

Literary Devices. (n.d.). Retrieved October 30, 2020 , from https://literarydevices.net/satire/

Martha22. (2014). Apa sih knock knock joke? CLOSED Crowdvoice.Com. https://id.crowdvoice.com/posts/apa-sihknock-knock-joke-closed-2xX4

Paputungan, R., Himpong, M., \& Tekkay, A. (2017). Persepsi Masyarakat Tentang Talkshow "Mata Nadjwa" Di Metro Tv (Studi Pada Masyarakat Bahu Kecamatan Malalayang). Acta Diurna Komunikasi, 6(2), $1-17$. https://ejournal.unsrat.ac.id/index.php/acta diurnakomunikasi/article/view/16567

Parmelee, J. H., \& Bichard, S. L. (2012). Politics and the Twitter Revolution: How Tweets Influence the Relationship between Political Leaders and The Public. Lexington Books.

Pragiwaksono, P., \& Fakhri, U. (2020). Pecahkan. Wongsoyudan Pratama Indonesia \& Institut Humor Indonesia Kini.

Prof. Dr. H. Mudjia Rahardjo, M. S. (2017). Studi Kasus Dalam Penelitian Kualitatif: Konsep Dan Prosedurnya (Vol. 6). http://repository.uinmalang.ac.id/1104/1/Studi-kasus-dalampenelitian-kualitatif.pdf

Ramadhanny, F. (2020). Arti Impostor dan 10 Cara Mendeteksinya di Game Among Us. Detik.Com. https://inet.detik.com/tipsdan-trik/d-5203257/arti-impostor-dan-10cara-mendeteksinya-di-game-among-us

Saifudin, A., Risagarniwa, Y. Y., Citraresmana, 
E., \& Sidiq, I. I. (2019). Pengembangan Alat Analisis Humor dalam Komik Jepang. Japanese Research on Linguistics, Literature, and Culture, 1(2), 129-143. https://doi.org/10.33633/jr.v1i2.2502

Setiawan, O. F., \& Ratyaningrum, F. (2018). Pertambangan Batu Kapur Sebagai Inspirasi Penciptaan Karya Batik Lukis. Jurnal Seni Rupa, 6(01), 796-805. https://jurnalmahasiswa.unesa.ac.id/index. $\mathrm{php} / \mathrm{va} /$ issue/view/1397

Shatz, M., \& Helitzer, M. (2016). Comedy Writing Secrets: The Best-Selling Guide to Writing Funny and Getting Paid For It. Writer's Digest Book.

Shifman, L, Levy, H., \& Thelwall, M. (2014). Internet Jokes: The Secret Agents of Globalization? Journal of ComputerMediated Communication, 19(4), 727743.

https://doi.org/http://doi.org/10.1111/jcc4. 12082

Shifman, Limor. (2014). Memes in Digital Culture. MIT Press Essential Knowledge.

Simon. (2019). The 'Empty Chair' Experience. Communication Media.

Simpson, P., \& Bousfield, D. (2017). Humor \& Stylistics. In S. Attardo (Ed.), The Routledge Handbook of Language and Humor (1st ed., p. 162). Routledge.

Sinclair, C. (2020). Parody: Fake News, Regeneration and Education. Postdigital Science and Education, 2(1), 61-77. https://doi.org/10.1007/s42438-01900054-X

Srisadono, W. (2018). Komunikasi Publik
Calon Gubernur Provinsi Jawa Barat 2018 dalam Membangun Personal Branding Menggunakan Twitter. Jurnal Pustaka Komunikasi. E-ISSN 2614-8498, diakses 25/05/2019. Jurnal Pustaka Komunikasi., 1(2), 213-227.

Sudarmo, D. M. (2013). HQ - Humor Quotient Kecerdasan Humor (D. Septriadi (Ed.); 1st ed.). Kombat Publishers.

Sudarmo, D. M. (2020). Anatomi Lelucon di Indonesia (3rd ed.). Institut Humor Indonesia Kini / IHIK3.

Tesnohlidkova, O. (2021). Humor and satire in politics: Introducing cultural sociology to the field. Sociology Compass, 15(1), 1-12. https://doi.org/10.1111/soc4.12842

Tsakona, V., \& Popa, D. E. (2011). Studies in Political Humor. John Benyamin Publishing.

Umrati, \& Wijaya, H. (2020). Analisis Data Kualitatif. Sekolah Tinggi Theologia Jaffray.

Valdez, N. (2020). Trending Indonesian Journalist Interviews an Empty Chair. POP! Inquirer.

Waisanen, D. J. (2018). The Rise of Advocacy Satire. In J. C. Baumgartner \& A. B. Becker (Eds.), Political Humor in a Changing Media Landscape: A New Generation of Research (First, pp. 11-28). Lexington Books.

Westacott, E. (2012). The Virtues of Our Vices: A Modest Defense of Gossip, Rudeness, and Other Bad Habits. Princeton University Press. 